\title{
Impact Of Adopting IAS-IFRS On The Handling Of Accounting Data: The Case Of France
}

\author{
Emna Boumediene, University of Manouba \& University of El Manar, Tunisia \\ Salem Lotfi Boumediene, Montana State University, USA \\ Olfa Nafti, University of Manouba, Tunisia
}

\begin{abstract}
In this article we look at the possible relation between the IAS-IFRS, which promotes a present value, and earnings management enhanced by the application of these standards. The aim of this paper is to analyse the impact of the adoption of IAS-IFRS standards on the earnings manipulation used by managers to manipulate their earnings and other accounting information in order to keep the same image in front of investors and shareholders.
\end{abstract}

We are expanding, to the French context, the problem of information content of the discretionary component of accounting income in connection with the application of IAS-IFRS since 2005.

On the basis of a sample of 96 firms-year observations, selected from France, that adopted the IAS-IFRS since 2005, we studied the relationship of association between accounting variables the impact of the use of IAS-IFRS on discretionary accruals. In other words, we tried to analyse the advantages and disadvantages of the adoption of IAS-IFRS.

The study results show that the manipulation of accounting information existed both before and after the adoption of IAS-IFRS. However, the application of IAS-IFRS accounting standards in France had less motivated managers to manipulate the accounting numbers to increase earnings. Infact, the degree of earnings management is higher before the adoption of IAS-IFRS (the manipulations were $22.06 \%$ of discretionary accruals after adoption of IAS-IFRS and $31.28 \%$ before).

Keywords: IAS-IFRS; Ratios; Dividend Yield; Accruals

\section{INTRODUCTION}

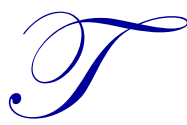

he financial statements published by companies to investors remain a source of insider information. Several empirical studies have shown the existence of an association between accounting variables and stock returns such as those of Daniel, Collins, \& Kothari (1989), Lev \& Thiagarajan (1993), Beaver et al. (1997), Kothari et al. (2003), and Bao (2004). In addition, some studies have shown the superiority of the explanatory power of accounting income on other accounting figures (Beaver et al., 1997; Kothari et al., 2003; Bao, 2004). Other studies are based on the usefulness and necessity of all the accounting variables issued by the firms. In fact, each variable has its own explanatory performance effect (Ali \& Zarowin, 1992; Lev \& Thiagarajan, 1993; Chan \& Seow, 1996; Kothari, 2001; Hung \& Subramanyam, 2004).

Some studies have shown that differences between national accounting systems affect the importance and credibility of accounting information (Hung, 2001; Ali \& Hwang, 2000; Ball et al., 2000; Pope \& Walker, 1999; Joos \& Lang, 1994; Alford et al., 1993). 
The International Accounting Standards (IAS), now renamed as International Financial Reporting Standards (IFRS), have been developed to harmonize corporate accounting practice and to answer the need for high quality standards to be adopted in the world's major capital markets.

Ball et al. (2003) argue that adopting high quality standards might be a necessary condition for high quality information, but not necessarily a sufficient one. According to Gelard (1989), it is necessary to adopt an effective procedure. This should not be a compromise between systems often contradictory among themselves, but by a rational choice for the most effective way to reach the goal. He also noted that we must not ignore the international character of the IAS-IFRS that may negatively affect some environments.

Other researchers agree that the global application of IAS-IFRS accounting standards would be difficult to achieve, even though that's what investors are looking for (Chamber, 1976; Nobes, 1995; Hoarau, 1995).

In addition, the IAS-IFRS are known by their flexibility. In fact, they enable managers to exercise their judgments to publish results based on discretionary targets (Watts \& Zimmerman, 1986, 1990). They seek their intervention to strengthen the information content of accounting figures in order to better inform the market about the prospects of the firm. According to Healy and Wahen (1999), the application of IAS-IFRS allows managers to exercise their discretion to adjust the financial statements based on circumstances and certain requirements. They believe that their intervention in the management of results increases the credibility of accounting information but also increases the level of discretionary accruals in the firm.

Contrary to most published studies on the subject, in this article we look at the possible relation between the IAS-IFRS, which promotes a present value, and manipulation of accounting results enhanced by the application of these standards.

In fact, in this paper we extend, to the French companies, the problem of information content of the discretionary component of accounting income in connection with the application of IAS-IFRS. A comparison of this context for Anglo-Saxon work is particularly interesting given the specificities of the French context.

The aim of this paper is to examine the merits of the change in accounting systems in France and to analyze the impact of this decision on the variation of the manipulation of accounting earnings under IAS-IFRS. We chose to compare the practices of performance management in different periods - pre-adoption (2003-2004) and postadoption (2006-2007).

\section{LITERATURE REVIEW AND HYPOTHESES}

The accruals allow the principle of matching costs with revenues in calculating the earning of the current year. However, these accruals may become subject to manipulation and adjustment of net income by the management. Part of manipulated accruals is called the discretionary accruals.

These adjustments can be made using different kinds of processes, referred to natural (Blanco et al., 2004; Heverals, 2007) and institutional (Ashbaugh \& Pincus, 2001; Santella \& Turrini, 2008).

Copeland (1968) defined manipulation as an opportunity to increase or decrease the net income implicitly recognizing that the concept of manipulation extends to both maximizing, minimizing, smoothing results, and fraud financial; but the handling is not limited to income (Barnea et al., 1975; Ronen \& Sadan, 1975; Barnea et al., 1976). They also include balance sheets and cash flow statements (Black et al., 1998). Given the multiplicity of forms of accounting manipulations, Stolowy \& Breton (2003) included these forms under the name of "management accounting data" which they define as "the exploitation of the discretion left to the leader's accounting policy choice or structuring transactions in order to generate a change in the risk of transfer of wealth associated with the company, as this risk is perceived in practice by the market." In practice, accounting manipulations combine practices which comply with the laws and standards from fraudulent practices. Academics often focus on the first where practitioners (including controllers) concentrate on the second (Dechow \& Skinner, 2000). Thus, according to Schillit (1993), the "tricks" are actions or omissions to hide or conceal the actual financial performance or the financial health of a company. 
Taking into account the discretionary component in the relationship between stock returns and accounting data in an environment using the IAS-IFRS is a relatively new problem and has become the subject of new research, especially after the last economic crisis.

The reasons for earnings management are many and studies that have addressed this subject are important. However, we focus on studies linking the impact of the adoption of IAS-IFRS with the degree of these manipulations and their relationship with the other accounting variables.

In their study, Ball et al. (2003) and Tendeloo and Vanstraelen (2005) showed that the informational quality of accounting information depends on the degree of adaptation of accounting standards to the country's economic environment. Ashbaugh \& Pincus (2001) went even further and concluded that the use of IFRS may increase or decline to publish the earnings, altering the information content of accounting and financial data.

In the same current of ideas, Tort (2006.a, 2006.b, 2006.c, 2007) confirmed the existence of a contingency of the accounting policy of listed companies studied in the context of transition to IFRS-consolidated accounts. He added that these companies adopt different trading strategies to IFRS while integrating structural and external constraints in these strategies in order to adjust their accounting policy disclosure. He also confirmed the results of Tendeloo and Vanstraelen (2005). Stolowy and Breton (2003) considered that the transition to IFRS helps managing accounting data by corporations and, more specifically, gives access to the information of a consolidated balance sheet. For Santella and Turrini (2008), the distribution of dividends computed on the basis of IAS-IFRS may lead to unrealistic profits and unjust enrichment. Using these standards as the basis for accounting generates changes in the traditional accounting methods and mechanisms. Aussenegg et al. (2009) chose to study the level of earnings management by replacing the local GAAP with IAS-IFRS, for 15 European countries using a sample of over 18,000 firms-years observations.

In their study, Aussenegg et al. (2009) tested four hypotheses:

1. Companies that adopted IAS-IFRS are not engaged in earning management more than those using local GAAP.

2. Growing companies tend to engage more earnings management.

3. Companies with significant cash flows have fewer earning management.

4. Companies with significant financial power tend to have more earnings management.

They include as independent variables, dummy variables for IAS/IFRS, the variable Time, the log of total assets to control for firm size effects, as well as three variables to test their hypotheses - revenue growth (in \%), operating cash flow scaled by lagged total assets (in \%), and the debt/equity ratio. The coefficient of the IAS/IFRSdummy variable is still negative but, in contrast to the previous regression, not significant. This indicates that earnings management only tends to be significantly lower for IAS/IFRS firms compared to local GAAP firms in two regions (German law countries - Austria, Germany, and Switzerland - and three French law countries - Belgium, France, and the Netherlands). The remaining eleven countries do not show a significant decline in earnings management by applying IAS/IFRS standards. As mentioned above, this is especially true for the two Anglo-Saxon and the four Scandinavian countries. Again, they do not observe a significant time effect, nor a firm size effect. In contrast, there is a positive effect for revenue growth and the debt/equity ratio.

Based on the use of discretionary accruals to stabilize the value of the outcome of the exercise, LaPointe et al. (2006) studied in the context of Switzerland, the effect of the use of accruals on the result set on the basis of IASIFRS, US GAAP, and Swiss standards. Their study shows that Swiss firms use discretionary accruals to stabilize results. They add that the value of these results decreases when calculated on the basis of IAS-IFRS or U.S. GAAP. This shows that the adoption of IAS-IFRS accounting treatment negatively affects the handling of earnings.

According to Lapointe et al. (2006), the structure of the accounting system of Switzerland is favorable to engage companies in earnings management. This system gives the Swiss companies the choice of measurement method and does not impose many rules and standards of substance (Achleitner, 1995; Raffournier, 1995). International standards allow companies to present users with more detailed information. To take advantage of the 
transparency and quality of this information, the Swiss financial market requires listed companies to publish financial statements prepared on the basis of IAS-IFRS. The purpose of this recommendation is to maintain the confidence of investors and shareholders who find it difficult to have information that assists them in making their decisions when financial statements are prepared on the basis of Swiss GAAP.

Using the approach of the information content, Wang and Williams (1994), Michelson et al. (1995), and Subramanyam (1996) showed that there is a relationship of positive association between income stability and stock returns. Using the approach of the relevance of accounting results, Habib (2004) found that the stability of income contributes to the decline in relevance.

According to Healy and Wahen (1999), the application of IAS-IFRS allows managers to exercise their discretion to adjust the financial statements based on circumstances and certain requirements. They believe that their intervention in earnings management increases the credibility of accounting information but also increases the level of discretionary accruals in the firm. Christensen et al. (2008) argue that firms' orientation to external - versus internal - financing affects their incentives to adopt IAS/IFRS early and to be more transparent (less earnings management) in their reporting. Early adoption of IFRS and a commitment to greater transparency reflects a tradeoff for managers of losing their informational advantage over external parties to the firm versus the benefits from being able to attract external financing to exploit growth opportunities. These arguments lead Christensen et al. to predict that firms with greater insider orientation will be less likely to adopt IFRS early. Consistent with this prediction, they find that firms that delayed adoption (resisters) have more bank ownership (where information asymmetries are resolved through private channels), higher long-term leverage, less often equity issue, and have a higher proportion of shares that are closely held. They also find that firms that delayed IAS-IFRS adoption make less financial analysis, suggesting these firms face less demand for transparent information from the capital markets. Christensen et al. (2008) analyze a sample of 310 German firms that adopted IAS-IFRS from 1998 to 2005. They compare earnings management (smoothing) metrics of early adopters (pre-2005) to late adopters (2005). They find a decrease in earnings management for the early adopters but a modest increase in earnings management (smoothing) for those firms that waited until IAS-IFRS became mandatory in Germany. They attribute these differences in results to early adopters' incentives to adopt IAS-IFRS in order to improve their earnings quality.

Jermakowicz and Gornik-Tomaszewski (2006) identified the main difficulties as 1) the complex nature of IAS-IFRS, 2) the lack of IAS/IFRS implementation guidance, and 3) the lack of uniform interpretation of IAS-IFRS. To the extent that these newly adopted accounting standards (IFRS after 2005) allow management greater flexibility in reporting earnings, we predict they will lead to greater earnings management (smoothing). Minimizing the cost of financing is an important motivation of financial manipulations. In the case of a capital increase, it is common to discover manipulation statements (Broye \& Schatt, 2002). Similarly, the reduction of the cost of capital (equity or debt), by applying a policy of smoothing results, can display a lower level of business risk (Stolowy \& Breton, 2003). From this literature, we can formulate the following assumptions:

H1: The use of discretionary accruals is associated with the value of debt and customers in French companies.

H1a: The use of discretionary accruals is associated with the value of debt and customers before the adoption of IAS-IFRS.

H1b: The use of discretionary accruals is associated with the value of debt and customers following the adoption of IAS-IFRS.

H2: The use of discretionary accruals is associated with the value of equity and yield.

H2a: The use of discretionary accruals is associated with equity value and yield prior to the adoption of IASIFRS.

H2b: The use of discretionary accruals is associated with the value of equity and yield after the adoption of IASIFRS.

H3: The adoption of IAS-IFRS helps to decrease earnings management. 


\section{METHODOLOGY}

\subsection{Background and Sample}

In this research, we selected a sample of 96 companies' year observations based on the French business firms (CAC 40) which adopted the IAS-IFRS since 2005. To study the impact of adoption on the manipulation of accounting figures, we chose two study periods - 2003-2004 prior to the adoption and 2006-2007after the adoption. The results obtained from both periods will be compared. We try to analyze the correlation relationship between discretionary accruals and accounting and financial data published by the French firms before and after the adoption of IAS-IFRS. We eliminated the financial companies and other enterprises with sector-based accounting rules. Our choice of the period from 2004 to 2007 is justified by the entry into application of IAS-IFRS by French firms.

\subsection{Variable of the Study}

\subsubsection{Accounting and Financial Variables}

The accounting and financial information were collected annually from French CAC 40 companies' websites and we were able to distribute transactions over the four financial years' (2003, 2004, 2006, and 2007) objects of study, in two sets. The first set, related to the cyclical or current operation, can isolate single concepts related to business activity - turnover, value added, operating surplus, and operating resources. The second, which considers aggregate behaviour, takes into account not only the operating functions, but other functions related to external growth, portfolio management, debts, and cash management, etc. This allows the study of different ratios related to the financial structure, margins and overall income and financing.

Among these ratios, 10 were selected in our study. They are the key points of the analysis made by financial analysts Baccouche and Nafti (2007) at the introduction of the company to the stock market or after its introduction.

The yield per share for a period of time t can be expressed as follows:

$R_{i t}=\frac{P_{i t+1}-P_{i t}+D_{i t}+d_{a t t}+d_{\text {sous }}}{P_{i t}}$

$\mathrm{P}_{\mathrm{it}}$ is the value of investment at beginning of the period.

$\mathrm{P}_{\mathrm{it}+1}$ is the value of this investment at end of the period.

$\mathrm{D}_{\mathrm{it}}$ is dividends paid during the period.

$d_{\text {att }}$ Represents the rights of attribution.

$\mathrm{d}_{\text {sous }}$ Represents the rights of subscription.

\subsubsection{Discretionary Accruals}

The measure of the degree of performance management used in our study is the value of discretionary accruals (DA). The estimation of discretionary accruals will be realized based on the model of Jones (1991) and on the model of Subramanyam (1996). However, to estimate discretionary accruals, one must first determine the total amount of accruals for each firm and each year. Due to lack of financial data for the application of the approach based on the balance sheet, we will use the cash flow approach to calculate total accruals in accordance with JeanJean's (2001) research.

The total accruals $\left(\mathrm{TA}_{\mathrm{it}}\right)$ are calculated as the difference between the net result of a year $\left(\mathrm{NR}_{\mathrm{it}}\right)$ and cash flows generated by the activity of the company during the same period $\left(\mathrm{CFE}_{\mathrm{it}}\right)$. Thus:

$\mathrm{TA}_{\mathrm{it}}=\mathrm{RN}_{\mathrm{it}}-\mathrm{CFE}_{\mathrm{it}}$

with 
$\mathrm{TA}_{\mathrm{it}}$ is the total accruals of the firm $\mathrm{i}$ in year $\mathrm{t}$.

$\mathrm{RN}_{\mathrm{it}}$ is the earnings of the firm $\mathrm{i}$ in year $\mathrm{t}$.

$\mathrm{CFE}_{\mathrm{it}}$ is the operations cash flow of the firm $\mathrm{i}$ in year $\mathrm{t}$.

The total accruals $\left(\mathrm{TA}_{\mathrm{it}}\right)$ can also be written as follow:

$\mathrm{TA}_{\mathrm{it}}=\mathrm{DA}_{\mathrm{it}}+\mathrm{NDA}_{\mathrm{it}}$

with

$\mathrm{TA}_{\mathrm{it}}$ : the total accruals for the firm $\mathrm{i}$ in year $\mathrm{t}$

$\mathrm{DA}_{\mathrm{it}}$ : the discretionary accruals of the firm $\mathrm{i}$ in year $\mathrm{t}$

$\mathrm{NDA}_{\mathrm{it}}$ : the non-discretionary accruals of the firm $\mathrm{i}$ in year $\mathrm{t}$

The modified Jones model (Dechow et al., 1995) is:

$\mathrm{TA}_{\mathrm{it}} / \mathrm{A}_{\mathrm{it}-1}=\alpha_{1}\left(1 / \mathrm{A}_{\mathrm{it}-1}\right)+\alpha_{2}\left(\left(\Delta \mathrm{CA}_{\mathrm{it}}-\Delta \mathrm{CRE}_{\mathrm{it}}\right) / \mathrm{A}_{\mathrm{it}-1}\right)+\alpha_{3}\left(\mathrm{IMMO}_{\mathrm{it}} / \mathrm{A}_{\mathrm{it}-1}\right)+\varepsilon_{\mathrm{it}}$

with

$\mathrm{TA}_{\mathrm{it}}$ : total accruals in period $\mathrm{t}$ for firm $\mathrm{i}$

$\Delta \mathrm{CA}_{\mathrm{it}}$ : change in turnover between $\mathrm{t}$ and $\mathrm{t}-1$ for firm $\mathrm{i}$

$\triangle \mathrm{CRE}_{\mathrm{it}}$ : change in receivables between $\mathrm{t}$ and $\mathrm{t}-1$ for firm $\mathrm{i}$

$\mathrm{IMMO}_{\mathrm{it}}$ : gross non-financial fixed assets in year $\mathrm{t}$ for firm $\mathrm{i}$

$\mathrm{A}_{\mathrm{it}-1}$ : Total Assets at end of period $\mathrm{t}-1$ for firm i

\subsection{Models of Accruals and Accounting Variables}

The multivariate analysis is used to estimate the coefficients of the regression model. First, this model allows us to demonstrate the association relationship between accounting variables (based on the IAS-IFRS) and discretionary accruals (DA). Second, it can analyze the same relationship between the accounting variables (based on local GAAP) and discretionary accruals.

$\mathrm{DA}_{\mathrm{it}}=\alpha_{0}+\alpha_{1}$ RES_NET/CA $+\alpha_{2} R E S \_N E T / C A P+\alpha_{3} C A / I M M O+\alpha_{4} P N C / C A P+\alpha_{5} C A P / I M M O+$ $\alpha_{6} P N C / R E S N E T+\alpha_{7} C A / C A P+\alpha_{8} C A / C L I+\alpha_{9} D I V+\alpha_{10} R E N D+v_{i}+\varepsilon_{t}$

with

$\mathrm{DA}_{\mathrm{it}}$ : discretionary accruals (in absolute value) $v_{\mathrm{i}}:$ represents the specific effects of companies $\varepsilon_{t}:$ represents the error term

The accounting variables are detailed in Table 1.

Table 1: Selected Accounting Variables

\begin{tabular}{|l|l|}
\hline Variables & \multicolumn{1}{|c|}{ Nature of Each Variable } \\
\hline$V_{1}$ & Earnings / Turnover (Performance) \\
\hline$V_{2}$ & Earnings / Equity \\
\hline$V_{3}$ & Turnover / Fixed Assets (Assets Turnover) \\
\hline$V_{4}$ & Non-Current Liabilities / Equity \\
\hline$V_{5}$ & Equity / Net Fixed Assets \\
\hline$V_{6}$ & Non-Current Liabilities / Earnings \\
\hline$V_{7}$ & Turnover / Equity (Equity Turnover) \\
\hline$V_{8}$ & Turnover / Customers (Customers Turnover) \\
\hline$V_{9}$ & Dividend per Share \\
\hline$V_{10}$ & Yield \\
\hline
\end{tabular}




\section{STUDY RESULTS}

The objective of our study is to examine the appropriateness of changes in accounting systems in France. It is also to analyze the impact of these decisions on the change in earnings manipulations in the context of IAS-IFRS. To analyze this impact, we have tried to find an association relationship between discretionary accruals and accounting variables in the French context before and after the adoption of IAS-IFRS.

\subsection{Before the Adoption of the IAS-IFRS}

The examination of the correlation matrix (Appendix 1) allows us to conclude the absence of mutlicolinearity for all the variables. In fact, according to Kennedy (1992), multicollinearity in a data set is considered if at least one simple correlation coefficient between the independent variables is at least 0.8 . The results presented in Table 2 are obtained through estimates based on the fixed effect model (OLS) since the null hypothesis for the Hausman test is rejected $(\mathrm{chi} 2=2.65$ and Prob $>$ chi $2=0.97)$.

The coefficients of the variables $\mathrm{V}_{4}$ and $\mathrm{V}_{8}$ are significant and negative (-0.066 and -0.03 , respectively). They explain the variation in discretionary accruals in respect of $31.43 \%$.

These variables are balance and profitability ratios. They allow investors to have a clear idea about the percentage of firm debt $\left(\mathrm{V}_{4}\right)$ and its ability to meet its long-term commitments and customer turnover $\left(\mathrm{V}_{8}\right)$. This result shows that French firms, before the adoption of IAS-IFRS, manipulate downward the value of long-term debt and increased the value of bad debt provisions due to the credit sales policy followed by the companies. These operations are of the order of $31.43 \%$ discretionary accruals. Thus, the flexibility of the French national standards enables managers to exercise their judgment to publish results based on discretionary objectives (Watts \& Zimmerman, 1986, 1990).

Table 2: Regression Results of DA to Accounting Variables (2003-2004)

\begin{tabular}{|c|c|c|c|}
\hline \multicolumn{4}{|c|}{ Model A: $D A_{i t}=\alpha_{0}+\alpha_{1} V_{1}+\alpha_{2} V_{2}+\alpha_{3} V_{3}+\alpha_{4} V_{4}+\alpha_{5} V_{5}+\alpha_{6} V_{6}+\alpha_{7} V_{7}+\alpha_{8} V_{8}+\alpha_{9} V_{9}+\alpha_{10} V_{10}+v_{i}+\varepsilon_{t}$} \\
\hline \multirow[b]{2}{*}{ Constant } & Parameter Estimate & $\mathbf{t}$ & Probability $>|\mathbf{T}|$ \\
\hline & 0,0776 & 0,97 & 0,331 \\
\hline$V_{1}$ & $-0,1848$ & $-0,48$ & 0,634 \\
\hline$V_{2}$ & 0,3154 & 1,13 & 0,4726 \\
\hline$V_{3}$ & $-0,1040$ & $-0,72$ & 0,47 \\
\hline$V_{4}$ & $-0,0663$ & $-3,17$ & $\mathbf{0 , 0 0 2}^{*}$ \\
\hline$V_{5}$ & 0,0077 & 0,2 & 0,843 \\
\hline$V_{6}$ & 0,0001 & 0,08 & 0,938 \\
\hline$V_{7}$ & 0,024 & 1,28 & 0,201 \\
\hline$V_{8}$ & $-0,03$ & $-2,59$ & $\mathbf{0 , 0 1}{ }^{*}$ \\
\hline$V_{9}$ & 0,0074 & 0,12 & 0,903 \\
\hline$V_{10}$ & 1,0827 & 1,44 & 0,151 \\
\hline \multicolumn{4}{|c|}{ Adjusted $R^{2}: 31,43 \%$} \\
\hline
\end{tabular}

According to Lapointe et al. (2006), the structure of the accounting system of Switzerland (national system like the French one) is favorable to engage companies in earnings management. This system gives the Swiss companies the choice of measurement method and does not impose many rules and standards of substance (Achleitner, 1995; Raffournier, 1995).

International standards allow companies to publish more detailed information than the Swiss GAAP. To take advantage of the transparency and quality of this information, the Swiss financial market requires listed companies to publish financial statements prepared on the basis of IAS-IFRS. International standards allow companies to publish more detailed information than the Swiss GAAP. In fact, to take advantage of the transparency and quality of this information, the Swiss financial market made mandatory for listed companies to publish financial statements prepared on the basis of IAS-IFRS. Furthermore, investors and shareholders consider that information contained in the financial statements prepared on the basis of Swiss GAAP as insufficient for decision-making. 
In addition, Aussenegg et al. (2009) show that countries belonging to the German legal system and some countries belonging to the French legal system experience a significant decline in performance management of their businesses compared to their counterparts that use local GAAP. They do observe neither a significant time effect nor a firm size effect. In contrast, there is a positive effect for revenue growth and the debt/equity ratio. Consequently, $\mathrm{H} 1 \mathrm{a}$ is verified.

Although the results of Model A show the magnitude of the coefficients of two variables in the variability of accruals, it is not acceptable to ignore the other variables in the model. Indeed, despite that the significance of their coefficient is low, we cannot rule out the model.

At this stage of the analysis, we need to eliminate the three variables with the lowest coefficient to identify hidden effects between other variables and accruals relations. These variables are $\mathrm{V}_{5}, \mathrm{~V}_{6}$, and $\mathrm{V}_{9}$. We obtained the results presented in Table 3.

We note that the results of our regression changed. In addition to the two variables that are significant in Model A, two other variables are also significant in the Model B. Indeed, the coefficients of the variables $\mathrm{V}_{7}$ and $\mathrm{V}_{10}$ are significant and positive ( 0.022 and 1.104 , respectively). These two variables measure, respectively, the equity turnover and economic efficiency.

Variable $\mathrm{V}_{7}$ allows us to appreciate how managers use the assets. This ratio is low $(<1)$ in the areas that require heavy investment and it is generally high $(>1)$ in the service sector. This ratio is important to our results. In fact, we can conclude that French firms, before the adoption of IAS-IFRS, invest significant resources to acquire assets and keep up with technology in order to attract investors and to maintain its image and reputation for the stakeholders. Our results enable us to conclude that the more the company is profitable $\left(\mathrm{V}_{10}\right)$, the more it can practice earnings management. These manipulations are $31.28 \%$ of discretionary accruals. Hence, H2a is verified.

Table 3: Regression Results of DA to the Remaining Accounting Variables (2003-2004)

\begin{tabular}{|c|c|c|c|}
\hline \multicolumn{4}{|c|}{ Model B: $D A_{i t}=\alpha_{0}+\alpha_{1} V_{1}+\alpha_{2} V_{2}+\alpha_{3} V_{3}+\alpha_{4} V_{4}+\alpha_{5} V_{7}+\alpha_{6} V_{8}+\alpha_{7} V_{10}+v_{i}+\varepsilon_{t}$} \\
\hline & Parameter Estimate & $\mathbf{t}$ & Probability $>\mid T$ \\
\hline Constant & 0,089 & 1,53 & 0,126 \\
\hline$V_{1}$ & $-0,189$ & $-0,52$ & 0,601 \\
\hline$V_{2}$ & 0,3145 & 1,27 & 0,203 \\
\hline$V_{3}$ & $-0,008$ & $-1,07$ & 0,283 \\
\hline$V_{4}$ & $-0,068$ & $-4,34$ & $\mathbf{0 , 0 0 0} *$ \\
\hline$V_{7}$ & 0,022 & 1,74 & $0,081^{* * *}$ \\
\hline$V_{8}$ & $-0,029$ & $-3,04$ & $0,002^{*}$ \\
\hline$V_{10}$ & 1,104 & 1,56 & $0,1^{* * * *}$ \\
\hline
\end{tabular}

Significant at: ${ }^{*} 1 \%,{ }^{* *} 5 \%$ and ${ }^{* * *} 10 \%(* * *)$

\subsection{After the Adoption of the IAS-IFRS}

This part of the analysis allows us to test the degree of accounting manipulation after the adoption of IASIFRS by French firms. Using the same approach than before the adoption of the IAS-IFRS, the examination of the correlation matrix (Appendix 2) allows us to conclude the absence of multicolinearity for all the variables since the largest correlation coefficient in Appendix 2 is less than .8.

The results of Model C (Table 4) show that the coefficients of the variables $V_{4}$ and $V_{7}$ are significant with different signs (-0.3388 and 0.3083 , respectively). French companies continue to handle their debts down even after the adoption of IAS-IFRS. They also follow the same policy of managing their resources to keep their brand and their investors. However, we note that these manipulations are of $22.19 \%$ discretionary accruals instead of $31.43 \%$ (Model A). 
Table 4: Regression Results of DA to Accounting Variables (2006-2007)

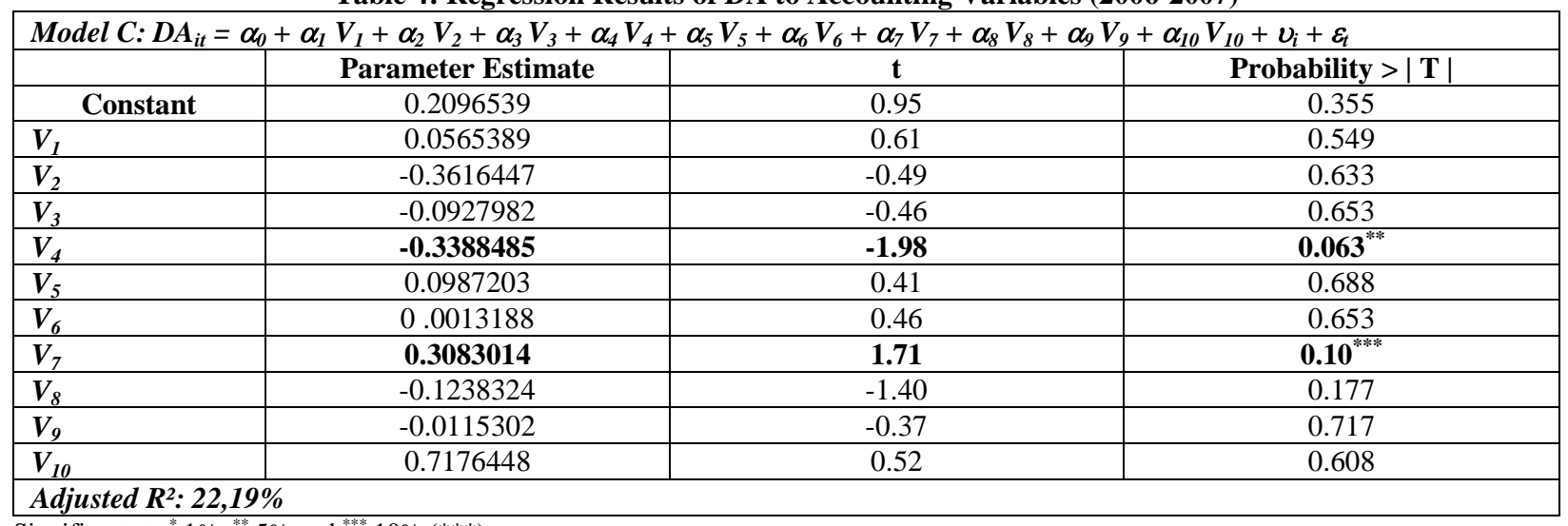

Significant at: ${ }^{*} 1 \%,{ }^{* *} 5 \%$ and ${ }^{* * *} 10 \%(* * *)$

In addition, the elimination of some variables, whose correlation coefficient is not significant, helped slightly to obtain better results (Table 5). Indeed, the elimination of variables $\mathrm{V}_{2}, \mathrm{~V}_{3}$, and $\mathrm{V}_{5}$, allowed the coefficient of the variable $\mathrm{V}_{8}$ to be negative and significant $(-0.142)$. This result confirms the ones of Models $\mathrm{A}$ and $\mathrm{B}$. However, we note that these manipulations are $21.06 \%$ of discretionary accruals instead of $31.28 \%$ (Model B). Consequently, $\mathrm{H} 1 \mathrm{~b}$ and $\mathrm{H} 2 \mathrm{~b}$ are verified.

Table 5: Regression Results of DA to the Remaining Accounting Variables (2006-2007)

\begin{tabular}{|c|c|c|c|}
\hline \multicolumn{4}{|c|}{ Model D: $D A_{i t}=\alpha_{0}+\alpha_{1} V_{1}+\alpha_{2} V_{4}+\alpha_{3} V_{6}+\alpha_{4} V_{7}+\alpha_{5} V_{8}+\alpha_{6} V_{9}+\alpha_{7} V_{10}+v_{i}+\varepsilon_{t}$} \\
\hline & Parameter Estimate & $\mathbf{t}$ & Probability $>|\mathbf{T}|$ \\
\hline Constant & 0.1913235 & 1.11 & 0.278 \\
\hline$V_{1}$ & 0.0232947 & 0.43 & 0.674 \\
\hline$V_{4}$ & -0.2943056 & -2.29 & $\mathbf{0 . 0 3 2}^{* *}$ \\
\hline$V_{6}$ & 0.0015555 & 0.78 & 0.445 \\
\hline$V_{7}$ & 0.2590664 & 2.07 & $\mathbf{0 . 0 5 1} 1^{* * *}$ \\
\hline$V_{8}$ & -0.1427198 & -2.01 & $0.057^{* *}$ \\
\hline$V_{9}$ & -0.0154701 & -0.57 & 0.576 \\
\hline$V_{10}$ & 0.8062302 & 0.64 & 0.529 \\
\hline \multicolumn{4}{|c|}{ Adjusted $R^{2}: 21,06 \%$} \\
\hline
\end{tabular}

\subsection{Summary of Results}

The results of our study (Table 6) show clearly that the manipulation of accounting figures exist before and after the adoption of IAS-IFRS. However, the adoption of international standards has helped to reduce the extent of this manipulation (31.28\% to $21.06 \%)$. Two reasons for this phenomenon are:

- $\quad$ Selected years 2006-2007 in our study provide the first two years after the adoption. It is a difficult transition for companies that need to develop a different traditional informational and accounting system, train their staff, and understand more prerogatives and benefits of this change. Therefore, managers show a certain distrust and caution in applying new and unfamiliar accounting policies.

- $\quad$ Some studies Nafti et al. (2013), Kothari et al. (2003), Mariam \& Jaques (2007), Bao (2004), and Aboody et al. (1999) have shown that the adoption of IAS-IFRS has a positive impact on earnings. Managers are then less motivated to manipulate their accounting numbers to increase earnings. They have been an automatic increase after the application of the fair value method. 
Table 6: Before and After IAS-IFRS Results Summary

\begin{tabular}{|l|c|c|}
\hline \multicolumn{2}{|c|}{$A D_{i t}=\alpha_{0}+\alpha_{1} V_{1}+\alpha_{2} V_{2}+\alpha_{3} V_{3}+\alpha_{4} V_{4}+\alpha_{5} V_{5}+\alpha_{6} V_{6}+\alpha_{7} V_{7}+\alpha_{8} V_{8}+\alpha_{9} V_{9}+\alpha_{10} V_{10}+v_{i}+\varepsilon_{t}$} \\
\hline$V_{1}$ & Before IAS-IFRS Adoption & After IAS-IFRS Adoption \\
\hline$V_{2}$ & & \\
\hline$V_{3}$ & $\mathrm{X}$ & $\mathrm{X}$ \\
\hline$V_{4}$ & & \\
\hline$V_{5}$ & & $\mathrm{X}$ \\
\hline$V_{6}$ & $\mathrm{X}$ & $\mathrm{X}$ \\
\hline$V_{7}$ & $\mathrm{X}$ & \\
\hline$V_{8}$ & & $\mathrm{X}$ \\
\hline$V_{9}$ & $31,28 \%$ & \\
\hline$V_{10}$ & & \\
\hline Adjusted $\boldsymbol{R}^{2}$ & & \\
\hline
\end{tabular}

Based on a sample of 353 French-listed groups relating to the period 2003-2006, the results of the paper of Zeghal et al. (2011) show that the mandatory adoption of IAS-IFRS is associated with a reduction in earnings level management. In addition, according to Zeghal et al. (2011), "the independence and the efficiency of the board of directors, the existence of an independent audit committee, the existence of block shareholders, the quality of the external audit and the listing on foreign financial markets are important for enforcement of IAS-IFRS in France. Mandatory adoption of IAS/IFRS has decreased earnings management level for companies with good corporate governance and those who depend on foreign financial markets." Thus, H3 is verified.

\section{CONCLUSION}

The IASB has established international standards (IAS-IFRS) to ensure more comparability and transparency, as well as better quality of financial statements. The establishment of such standards by the IASB aims at achieving harmonization of accounting practices between countries.

Some studies have shown that differences between national accounting systems affect the importance and credibility of accounting information (Hung, 2001; Ali \& Hwang, 2000; Ball et al., 2000; Pope \& Walker, 1999; Joos \& Lang, 1994; Alford et al., 1993). This flexibility allows managers to exercise their decision to publish earnings based on discretionary targets (Watts \& Zimmerman, 1986, 1990). They seek their intervention to strengthen the information content of accounting figures in order to better inform the market about the prospects of the firm.

In this article, we are interested in the relationship that may exist between the IAS-IFRS, which promotes a present value, and the manipulation of earnings enhanced by the application of these standards. We are expanding, to the French context, the problem of information content of the discretionary component of accounting earnings in connection with the application of IAS-IFRS.

On the basis of a sample of 96 firms-year observations from France, which adopts the IAS-IFRS since 2005, we studied the impact of the use of IAS-IFRS on discretionary accruals in this relationship. The study results show that the application of IAS-IFRS accounting standards in France had less motivated managers to manipulate their accounting numbers to increase earnings. In fact, the degree of earnings management is higher before the adoption of IAS-IFRS (the manipulations were $22.06 \%$ of discretionary accruals after adoption of IAS-IFRS and $31.28 \%$ before).

We can say that before the adoption of IAS-IFRS, French firms manipulated downward the value of longterm debt and increased the value of bad debt provisions due to the credit sales policy followed by the companies. We can also conclude that French firms, before the adoption of IAS-IFRS, invest significant resources to acquire property and keep up with technology in order to attract investors and keep its brand image and reputation against the partners and shareholders. Finally, our findings allow us to conclude that when the company is more profitable (REND), it can practice more earnings management. 
In addition, we can also conclude that, after the adoption of IAS-IFRS, the French companies continue to manipulate their accounting numbers by reducing their debts and increasing their provisions but at a lower degree than before the adoption. We also notice that REND, which is the variable measuring the performance of the firm, is not significant after the adoption. This result can be explained by the fact that the performance is much related to the current value. The French companies had better performance after the adoption than before because of their updated financial statements. Finally, our results confirm those of Zeghal et al. (2011) and Aussenegg et al. (2009).

\section{AUTHOR INFORMATION}

E. Boumediene has a PhD in Business Administration (Accounting) from the University of El Manar, Tunisia. Dr. Boumediene is an Assistant Professor in the Department of Accounting and Finance at ISCAE, La Manouba, Tunisia. Dr. Boumediene teaches both financial and managerial accounting at the undergraduate and graduate levels. She also taught courses for preparation of the Certified Public Accounting exam. Dr. Boumediene has been publishing her scientific research in academic journals and published a book on the Financial Statement. E-mail: emna boumediene@yahoo.fr

S. L. Boumediene has a $\mathrm{PhD}$ in Business Administration (Accounting) from the University of El Manar, Tunisia. Before joining Montana State University-Billings, Dr. Boumediene taught both financial and managerial accounting at both the undergraduate and graduate levels at the top business schools in Tunisia. Dr. Boumediene has been publishing his research work in academic journals, such as Journal of Modern Accounting and Auditing and the Journal of Management and Business Research, among others. Dr. Boumediene published a book on statistical characteristics and quality of accounting information in 2013. E-mail: salem.boumediene@msubillings.edu (Corresponding author)

O. Nafti has a PhD in Business Administration (Accounting) from the University of Tunis, Tunisia. Dr. Nafti is an Assistant Professor in the Department of Accounting and Finance at ISCAE, La Manouba, Tunisia. Dr. Nafti teaches both financial and managerial accounting at the undergraduate and graduate levels. Dr. Nafti has been publishing her scientific research in academic journals and made several presentations in several conferences in Tunisia and France. E-mail: olfa.nafti@iscae.rnu.tn

\section{REFERENCES}

1. Aboody, D., Barth, M., \& Kasznik, R. (1999). Revaluation of fixed asset and future firm performance. Journal of Accounting and Economics, 26, 149-178.

2. Achleitner, A. (1995). Latest developments in Swiss regulation of financial reporting. European Accounting Review, 4(1), 141-164.

3. Alford, A., Jones, J., Leftwich, R., \& Zmijewski, M. (1993). The relative informativeness of accounting disclosures in different countries. Journal of Accounting Research, 31(supplement), 183-223.

4. Ali, A., \& Hwang, L. S. (2000). Country-specific factors related to financial reporting and the value relevance of accounting data. Journal of Accounting Research, 38, 1-21.

5. Ali, A., \& Zarowin, P. (1992). The role of earnings levels in annual earnings-returns studies. Journal of Accounting and Research, 30, 286-296.

6. Ashbaugh, H., \& Pincus, M. (2001). Domestics accounting standards, international accounting standards and the predict-ability of earnings. Journal of Accounting Research, 39(3), 417-434.

7. Aussenegg, W., Inwinkl, P., \& Schneider, G. (2009). Earning management and accounting standards in Europe. MFA Annual Meeting.

8. Ball, R., Kothari, S. P., \& Robin, A. (2000). The effects of international factors on properties of accounting earnings. Journal of Accounting and Economics, 29, 1-51.

9. Ball, R., Robin, A., \& Wu, J. S. (2003). Incentives versus standards: Properties of accounting income in four East Asian countries. Journal of Accounting and Economics, 36(1-3), 235-270.

10. Bao, Y. (2004). Do financial analyses play a role in valuation? Evidence from Asian stock markets. (Working Papers Series). American Accounting Association. Frostburg State University.

11. Barnea, A., Ronen, J., \& Sadan, S. (1975). The implementation of accounting objectives: An application to extraordinary items. The Accounting Review, January, 58-68. 
12. Barnea, A., Ronen, J., \& Sadan, S. (1976). Classificatory smoothing of income with extraordinary items. The Accounting Review, January, 110-122.

13. Beaver, W., McAnally, M., \& Stinson, C. (1997). The information content of earnings and prices: A simultaneous equations approach. Journal of Accounting and Economics, 23, 53-81.

14. Black, E. L., Sellers, K. F., \& Manly, T. S. (1998). Earnings management using asset sales: An international study of countries allowing noncurrent asset revaluation. Journal of Business Finance \& Accounting, 25(9 \& 10), 1287-1317.

15. Blanco, J. L. U., \& Garcia Osma, B. (2004). The comparability of international accounting standards and US GAAP: An empirical study of form 20-F reconciliations. International of Accounting, Auditing and Performance Evaluation Olney, 1(1), 5.

16. Bohrstedt, G., \& Knoke, D. (1994). Statistics for social data analysis (3 ${ }^{\text {rd }}$ ed.). I Tasca, IL: F. E. Peacock Publishers.

17. Boukari, M., \& Richard, J. (2007). Accounting implications of the transition to IFRS for the French listed groups. Accounting Control Audit, 13, 155-170.

18. Broye, G., \& Schatt, A. (2002). Comment réduire la sous-évaluation lors de l'introduction en bourse? Direction et Gestion, 196-197, 31-40.

19. Chamber, R. J. (1976). Correspondence, the possibility of a normative accounting standard. The Accounting Review, 3, 646-652.

20. Christensen, H. B., Lee, E., \& Walker M. (2008). Incentives or standards: What determines accounting quality changes around IFRS adoption? AAA 2008 Financial Accounting and Reporting Section (FARS) Paper. Retrieved from http://ssrn.com/abstract=1013054

21. Copeland, R. M., \& Wojdak, J. F. (1969). Income manipulation and the purchase-pooling choice. Journal of Accounting Research, Autumn, 188-195.

22. Daniel, W., Collins, S., \& Kothari, P. (1989). An analysis of intertemporal and cross-sectional determinants of earnings response coefficients. Journal of Accounting and Economics, 11, 143-181.

23. Dechow, P., Sloan, R., \& Sweeney, A. (1995). Detecting earnings management. Accounting Review, 70(2), 193-225.

24. Gelard, G. (1989). The universe of standards, national and international standardization. The French Accounting Review, 203, 58-61.

25. Habib, A. (2004). Impact of earnings management on value-relevance of accounting information: Empirical evidence from Japan. Managerial Finance, 30(11), 1-15.

26. Healy, P. M., \& Wahlen, J. M. (1999) Are view of the earnings management literature and its implications for standard setting. Accounting Horizons, 13(4), 365-383.

27. Heverals, J. (2007). IAS/IFRS in Belgium: Qualitative analysis of the impact on the tax burden of companies. Journal of International Accounting Auditing and Taxation Greenwich, 16(1), 69.

28. Hoarau, C. (1995). International accounting harmonization, American hegemony or mutual recognition with benchmarks? The European Accounting Review, 217-233.

29. Hung, M. (2001). Accounting standards and value relevance of financial statements: An international analysis. Journal of Accounting and Economics, 30, 401-420.

30. Hung, M., \& Subramanyam, K. R. (2007). Financial statement effects of the adoption of international accounting standards: The case of Germany. Review of Accounting Studies, 12(4), 623-657.

31. JeanJean, T. (2001). Incentives and constraints to earnings management. Accounting Control Audit, 7(1), 61-76.

32. Jones, J. (1991). Earnings management during import relief investigations. Journal of Accounting Research, 29, 193-228.

33. Jermakowicz, E. K., \& Gornik-Tomaszewski, S., (2006) Implementing IFRS from the perspective of EU publicly traded companies. Journal of International Accounting, Auditing and Taxation, 15, 170-196.

34. Joos, P., \& Lang, M. (1994). The effects of accounting diversity: Evidence from the European Union. Journal of Accounting Research, 32(supplement), 141-168.

35. Kam, C., Chan, G., \& Seow, S. (1996). The association between stock returns and foreign GAAP earnings versus earnings adjusted to US GAAP. Journal of Accounting and Economics, 21, 139-158.

36. Kothari, S. P., Lewallen, J., \& Warmen, J. B. (2003). Stock returns, aggregate earnings surprises and behavioural finance. (MIT Sloan Working paper n4284-03 Simon School of Business Working paper $\left.\mathrm{n}^{\circ} \mathrm{FR} 03-05\right)$. 
37. Lapointe-Antunes, P., Cormier, D., Magnan, M., \& Gay-Angers, S. (2006). On the relationship between voluntary disclosure, earnings smoothing and the value-relevance of earning: The case of Switzerland. European Accounting Review, 15(4), 465-505.

38. Lev, B., \& Thiagarajan, S. R. (1993). Fundamental information analysis. Journal of Accounting Research, 31(2), 190-215.

39. Michelson, S. et al (1995). A market-based analysis of income smoothing. Journal of Business, Finance and Accounting, December, 1179-1193.

40. Nafti Bakini, O., \& Baccouche, C. M. (2007). The association relationship between stock returns and accounting numbers. Estimate panel data: The case of Tunisia. Accounting Control Audit, 13, 107-135.

41. Nafti, O., Boumediene, E., \& Boumediene, S. L. (2013). IAS-IFRS adoption impact on accounting information: The case of France. Journal of Modern Accounting and Auditing, 9(3), 321-334.

42. Nobe, C. (1995). International accounting harmonization, a commentary? The European Accounting Review, 249-254.

43. Pope, P. F., \& Walker, M. (1999). International differences in the timeliness, conservatism and classification of earnings. Journal of Accounting Research, 37(supplement), 53-87.

44. Raffournier, B. (1995). The determinants of voluntary financial disclosure by Swiss listed companies. European Accounting Review, 4(2), 261-280.

45. Ronen, J., \& Sadan, S. (1975a). Classificatory smoothing: Alternative income models. Journal of Accounting Research, Spring, 133-149.

46. Ronen, J., \& Sadan, S. (1975b). Do corporations use their discretion in classifying accounting items to smooth reported income? Financial Analysts Journal, 31(5), 62-68.

47. Santella, P., \& Turrini, R. (2008). Capital maintenance in the EU: Is the second company law directive really that restrictive? European Business Organisation Law Review Cambridge, 9(3), 427-462.

48. Schilit, H. M. (1993). Financial shenanigans: How to detect accounting gimmicks and fraud in financial reports. New York: McGraw Hill.

49. Stolowy, H., \& Breton, G. (2003). The management of accounting date: A literature review. Accounting Control Audit, 9(1), 125-152.

50. Subramanyam, K. R. (1996). The pricing of discretionary accruals. Journal of Accounting and Economic, 22(1-3), 249-281.

51. Tendeloo, B. V., \& Vanstraelen, A. (2005). Earnings management under German GAAP versus IFRS. European Accounting Review, 14(1), 155-180.

52. Tort, E. (2006.a). Financial reporting. DUNOD.

53. Tort, E. (2006.b). A case study of earnings management practices. European Financial and Accounting Journal, 1(4), 16-41.

54. Tort, E. (2006.c). The accounting and financial practices of listed companies: The French case. Management Revue, 3(1), 21-32.

55. Tort, E. (2007.d). Financial reporting and accounting policy of French listed companies: A review. Gestion 2000, 02(07).

56. Wang, Z., \& Williams, T. (1994). Accounting income smoothing and stockholder wealth. Journal of Applied Business Research, Summer, 96-104.

57. Watts, R., \& Zimmerman, J. (1986). Positive accounting theory. Englewood Cliffs: Prentice-Hall.

58. Watts, R., \& Zimmerman, J. (1990). Positive accounting theory. A ten year perspective. The Accounting Review, 65(1), 131-156.

59. Zéghal, D., Chtourou, S., \& Mnif Sellami, Y. (2011). An analysis of the effect of mandatory adoption of IAS/IFRS on earnings management. Journal of International Accounting, Auditing and Taxation, 20, 6172 . 


\section{APPENDICES}

Appendix 1: Correlation Matrix before IAS-IFRS Adoption

\begin{tabular}{|c|c|c|c|c|c|c|c|c|c|c|c|}
\hline Variables & AD & RES_NET/CA & RES_NET/CAP & CA/IMMO & PNC/CAP & CAP/IMMO & PNC/RES_NET & CA/CAP & CA/CLI & DIV & REND \\
\hline $\mathrm{AD}$ & 1.000 & & & & & & & & & & \\
\hline $\begin{array}{l}\text { RES } \\
\text { NET/CA }\end{array}$ & 0.0684 & 1.000 & & & & & & & & & \\
\hline $\begin{array}{l}\text { RES } \\
\text { NET/CAP }\end{array}$ & 0.0507 & 0.4944 & 1.000 & & & & & & & & \\
\hline CA/IMMO & -0.1164 & -0.1194 & 0.4068 & 1.000 & & & & & & & \\
\hline $\mathrm{PNC/CAP}$ & -0.2719 & -0.3376 & 0.1948 & -0.1111 & 1.000 & & & & & & \\
\hline CAP/IMMO & -0.0066 & 0.3474 & 0.0923 & 0.5737 & -0.7078 & 1.000 & & & & & \\
\hline $\begin{array}{l}\mathrm{PNC} / \mathrm{RES} \\
\mathrm{NET}\end{array}$ & -0.1473 & -0.2916 & -0.1143 & -0.1950 & 0.6984 & -0.5252 & 1.000 & & & & \\
\hline CA/CAP & -0.0622 & -0.5617 & 0.3530 & 0.5065 & 0.5866 & -0.3260 & 0.3012 & 1.000 & & & \\
\hline CA/CLI & -0.3437 & 0.0946 & 0.2626 & 0.2214 & 0.1144 & -0.0230 & -0.0551 & 0.2356 & 1.000 & & \\
\hline DIV & -0.0208 & 0.1179 & 0.2289 & 0.1179 & -0.0208 & -0.0486 & -0.1318 & 0.0763 & 0.2151 & 1.000 & \\
\hline REND & 0.1349 & 0.2058 & 0.2515 & -0.1061 & 0.2091 & -0.2658 & 0.1427 & 0.0504 & 0.0987 & 0.1897 & 1.000 \\
\hline
\end{tabular}

Appendix 2: Correlation Matrix after IAS-IFRS Adoption

\begin{tabular}{|c|c|c|c|c|c|c|c|c|c|c|c|}
\hline Variables & AD & RES_NET/CA & RES_NET/CAP & CA/IMMO & PNC/CAP & CAP/IMMO & PNC/RES_NET & CA/CAP & CA/CLI & DIV & REND \\
\hline $\mathrm{AD}$ & 1.000 & & & & & & & & & & \\
\hline $\begin{array}{l}\text { RES } \\
\text { NET/CA }\end{array}$ & -0.175 & 1.000 & & & & & & & & & \\
\hline $\begin{array}{l}\text { RES } \\
\text { NET/CAP }\end{array}$ & -0.234 & 0.506 & 1.000 & & & & & & & & \\
\hline CA/IMMO & -0.217 & -0.463 & -0.027 & 1.000 & & & & & & & \\
\hline $\mathrm{PNC/CAP}$ & -0.078 & -0.24 & 0.2 & -0.228 & 1.000 & & & & & & \\
\hline CAP/IMMO & 0.1523 & 0.008 & -0.232 & 0.6 & -0.76 & 1.000 & & & & & \\
\hline $\begin{array}{l}\mathrm{PNC} / \mathrm{RES} \\
\mathrm{NET}\end{array}$ & 0.1937 & -0.35 & -0.244 & -0.11 & 0.611 & -0.497 & 1.000 & & & & \\
\hline CA/CAP & -0.08 & 0.484 & 0.356 & 0.485 & 0.475 & -0.31 & 0.257 & 1.000 & & & \\
\hline CA/CLI & -0.36 & 0.1724 & 0.525 & -0.075 & 0.04 & -0.23 & -0.247 & 0.268 & 1.000 & & \\
\hline DIV & -0.25 & 0.3533 & 0.191 & -0.297 & 0.061 & -0.31 & -0.065 & -0.075 & 0.273 & 1.000 & \\
\hline REND & 0.266 & -0.228 & -0.176 & 0.3785 & 0.07 & 0.218 & -0.015 & 0.14 & -0.3184 & -0.036 & 1.000 \\
\hline
\end{tabular}

